\title{
ASSESSMENT OF HEAVY METAL CONCENTRATION IN MARINE SEDIMENTS IN TERENGGANU WATERS
}

\author{
YIP TAIM HING ${ }^{1}$, TAN EVONNE ${ }^{1}$, POONG JUN HAN ${ }^{1}$, TEE LIAN SHENG ${ }^{1}$, MUHAMMAD \\ HASBI RAMLI ${ }^{1}$, ASNOR AZRIN SABUTI² AND ONG MENG CHUAN ${ }^{1,3,4^{*}}$
}

${ }^{\text {I}}$ Faculty of Science and Marine Environment, Universiti Malaysia Terengganu, 21030 Kuala Nerus, Terengganu, Malaysia ${ }^{2}$ Kulliyyah of Science, International Islamic University Malaysia, 25200 Kuantan, Pahang, Malaysia

${ }^{3}$ Institute of Oceanography and Environment, Universiti Malaysia Terengganu, 21030 Kuala Nerus, Terengganu, Malaysia ${ }^{4}$ Ocean Pollution and Ecotoxicology (OPEC) Research Group, Universiti Malaysia Terengganu, 21030 Kuala Nerus, Terengganu, Malaysia

*Corresponding author: ong@umt.edu.my

http://doi.org/10.46754/umtjur.2021.04.001

\begin{abstract}
The distribution of heavy metals $(\mathrm{Cu}, \mathrm{Zn}, \mathrm{Cd}, \mathrm{Pb})$ in surface sediments was examined in waters off the coast of Marang, Terengganu. A total of 20 samples were collected using Ponar grab and analysed by inductively coupled plasma-mass spectrometer after closed digestion with acid. The sediments were filtered using a dry sieving method to determine their particle size. The spatial distribution maps on the concentration of selected metals were drawn using the ArcGIS software. Results showed that the average concentration of $\mathrm{Cu}, \mathrm{Zn}, \mathrm{Cd}$, and $\mathrm{Pb}$ were $2.33 \pm 0.38 \mu \mathrm{g} / \mathrm{g}$ dry weight, $28.4 \pm 3.78 \mu \mathrm{g} / \mathrm{g}$ dry weight, $0.09 \pm 0.01 \mu \mathrm{g} / \mathrm{g}$ dry weight and $8.35 \pm 1.48 \mu \mathrm{g} / \mathrm{g}$ dry weight, respectively. The level of pollution was also evaluated using the Index of Geoaccumulation $\left(\mathrm{I}_{\text {geo }}\right)$ and Pollution Load Index (PLI). All $\mathrm{I}_{g e o}$ and PLI values obtained were low, which indicated low or no pollution. Meanwhile, the sediment mean size ranged between $-0.77 \varnothing$ and $3.18 \varnothing$, which characterised a sandy type of sediment. Correlation analysis showed a positive correlation between the heavy metals and sediment size. The results indicated that there was a common source of heavy metal pollution in the study area, possibly from shipping activities. Overall, there was no significant heavy metal pollution in the waters off Marang. This finding is important as the data could be used to evaluate the risk of metal contamination and the impact of anthropogenic activities on the marine environment.
\end{abstract}

Keywords: Heavy metals, sediment, index of geoaccumulation, pollution load index, South China Sea

\section{Introduction}

Heavy metal accumulation in river sediments caused by human activities, such as mining and industrial waste discharge, is common in developing countries (Islam et al., 2015), including Malaysia. Nowadays, rivers have become a "sink" for heavy metal accumulation, where their sediments may retain those metals and cause toxicity in the aquatic environment (Li et al., 2013). Heavy metal pollution is also becoming common (Iwuoha et al., 2012) and is among the serious global environmental concerns because they are toxic, nonbiodegradable, widespread and accumulative in organisms (Ong et al., 2015; Fu \& Wang, 2011). The metals in the water column may be derived from two sources - natural and anthropogenic (Dalman et al., 2006). According to Ghrefat and Yusuf (2006), the weathering of rocks and volcanic activities are examples of natural sources that may introduced heavy metals into the aquatic system. Meanwhile, most of the anthropogenic sources come from human activities, such as agricultural runoff, untreated sewage, aquaculture, mining and industrial waste (Kamaruzzaman et al., 2010).

Marine sediments mostly comprise aluminosilicate minerals and originate from the weathering of rocks and soil erosion (Esen et al., 2010). Heavy metal pollution in the seawater is strongly associated with marine sediments (Horowitz, 1991). The study 
of marine sediments is vital to assess such pollution as the sediments have longer residence time in the ocean environment (Lin et al., 2008). When the dissolved heavy metals from natural or anthropogenic sources mix with sea water, they are removed from the water column by adsorbing to marine sediments at a very fast rate (Esen et al., 2010). The adsorption rate of heavy metals will increase with decreasing grain size of the sediments (Esen et al., 2010). Therefore, fine marine sediments will contain higher concentrations of heavy metals compared to those with larger grain size due to the high specific surface adsorption of the smaller particles (Zhang et al., 2007). Thus, heavy metal concentration is significantly higher in finegrained sediments that are rich in clay minerals (Abrahim et al., 2007), especially surficial sediments that may act as a "pool" or "sink" for such metals (Wang et al., 2008). However, heavy metals in marine sediments will undergo remobilisation as the chemical environment changes (Zoumis et al., 2001). For example, a drop in $\mathrm{pH}$ valuedue to ocean acidification will cause the remobilisation of the heavy metals (Yuan et al., 2004).

Marine sediments are useful indicators in the assessment of heavy metal pollution (Nowrouzi et al., 2014). Some metals such as copper $(\mathrm{Cu})$ and zinc $(\mathrm{Zn})$ are essential to the metabolism and growth of living organisms at low concentration, while cadmium $(\mathrm{Cd})$ and plumbum $(\mathrm{Pb})$ are extremely toxic even at low quantities (Jian-Guo et al., 2010; Peng et al.,
2008). Therefore, the objectives of this study are to determine the concentration of selected heavy metals, namely $\mathrm{Cu}, \mathrm{Zn}, \mathrm{Cd}, \mathrm{Pb}$ in the ocean waters off the coastal district of Marang in the state of Terengganu, Malaysia, to assess the level of pollution in the surficial sediments using the Geoaccumulation Index $\left(\mathrm{I}_{\text {geo }}\right)$ and pollution load index (PLI).

\section{Materials and Methods}

Marang town is located in a coastal district with the same name in the state of Terengganu on the east coast of Peninsular Malaysia. The district is adjacent to the South China Sea and the main economic activities are fishing and tourism. The resort island of Pulau Kapas is located off the district's coast, and shipping traffic is quite heavy between the island and mainland.

Sampling was carried out aboard the UMT Discovery VII, a research vessel belonging to Universiti Malaysia Terengganu, on September 21, 2018. Sediment samples were collected using a Ponar grab at 20 stations shown in the map of the study area in Figure 1. The outermost layer of the sediment samples was removed to avoid metal contamination from the wall of the grab, and the inner part was placed in plastic containers. The plastic containers were kept in an ice chest under low temperature (Niu et al., 2009; Kamaruzzaman et al., 2010; 2011). The coordinates of each station were recorded using the Global Positioning System (GPS). 


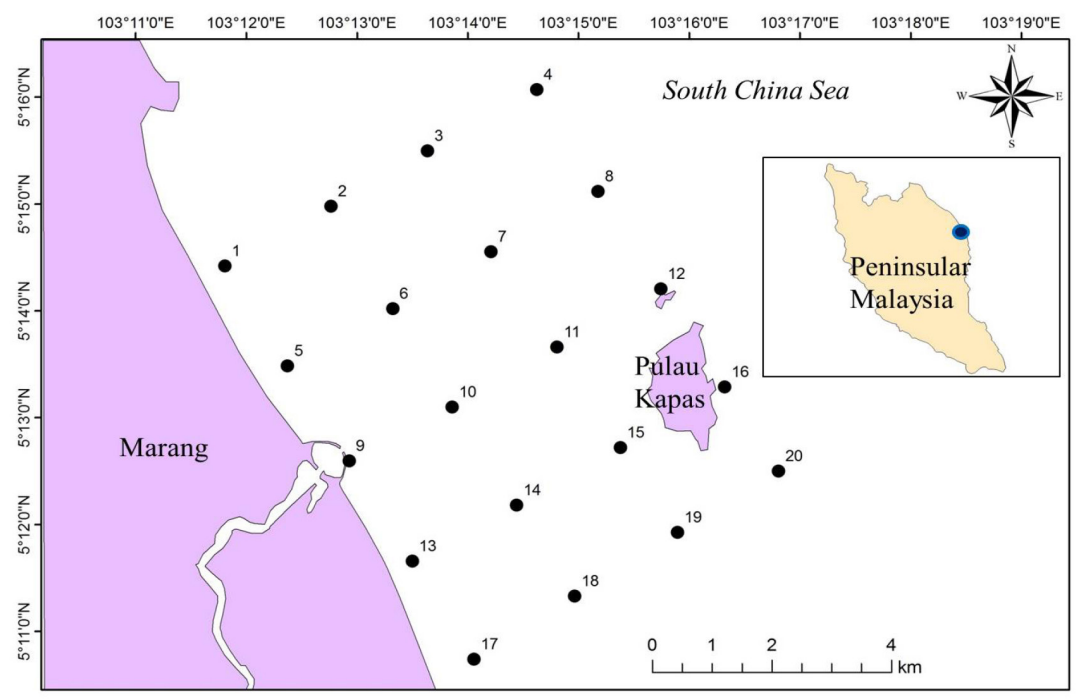

Figure 1: Map of sampling stations located in the study area off the coast of Marang

All glass and plastic apparatus were soaked in $10 \% \mathrm{HNO}_{3}$ overnight and rinsed with Mili-Q water (Merck KGaA, Darmstadt, Germany) before use (Ong et al., 2013). The Teflon beakers used for sample digestion were boiled in $65 \%$ for one hour to prevent contamination. After boiling, the beakers were dried in an oven at $80^{\circ} \mathrm{C}$ for one hour.

The sediment samples were defrosted at room temperature and dried in an oven at $60^{\circ} \mathrm{C}$ until the weight became constant. The dried samples were ground using mortar and pestle (Gargouri et al., 2011) before being homogenised and stored in clean polypropylene containers.

The sediment samples were first processed using the "Teflon Bomb" digestion method and total heavy metal content was determined using inductively coupled plasma-mass spectrometry (ICP-MS) as described by Ong et al. (2013; 2015). Briefly, $50 \mathrm{mg}$ of the homogenised samples with grain size of less than $63 \mu \mathrm{m}$ was mixed with $1.5 \mathrm{~mL}$ of concentrated hydrofluoric acid (HF), and $\mathrm{HCl}$ in sealed Teflon vessels. The Teflon vessels were heated at $100^{\circ} \mathrm{C}$ for eight hours. After cooling at room temperature, the solution in the vessels was transferred into a polypropylene tube and diluted to 10 $\mathrm{mL}$ with deionised water. The digested and diluted samples were then loaded into the ICPMS system to determine the concentration of $\mathrm{Cu}, \mathrm{Zn}, \mathrm{Cd}$, and $\mathrm{Pb}$. The Standard Reference Material 1646a Estuarine Sediment was used for the recovery test.

To analyse the sediment particle size, $200 \mathrm{~g}$ of samples were allocated for the dry sieving technique. A sieve shaker with mesh sizes ranging from $63 \mu \mathrm{m}$ to $4,000 \mu \mathrm{m}$, was used to filter the samples. After 10 minutes, the remaining sediment samples trapped at each mesh were weighed. The GRADISTAT particle size analysis software (Kenneth Pye Associates Ltd, Wokingham, UK) was used to determine the characteristics of the sediments.

\section{Results and Discussion}

The Standard Reference Material 1646a Estuarine Sediment was used to assess the accuracy of the experiment. The recovery percentages of $\mathrm{Cu}, \mathrm{Zn}, \mathrm{Cd}, \mathrm{Pb}$ are shown in Table 1. Cd seemed to have the highest recovery percentage at $101.35 \%$, while $\mathrm{Zn}$ had the lowest percentage at $88.96 \%$. 
Table 1: Results of the recovery test for $\mathrm{Cu}, \mathrm{Zn}, \mathrm{Cd}$, and $\mathrm{Pb}$

\begin{tabular}{cccc}
\hline Heavy metal & $\begin{array}{c}\text { Measured values } \\
(\boldsymbol{\mu g} / \mathbf{g} \text { dry weight) }\end{array}$ & $\begin{array}{c}\text { Certified values } \\
(\boldsymbol{\mu g} / \mathbf{g} \text { dry weight) }\end{array}$ & Recovery percentage (\%) \\
\hline $\mathrm{Cu}$ & $9.28 \pm 0.71$ & $10.01 \pm 0.34$ & 92.7 \\
$\mathrm{Zn}$ & $43.5 \pm 2.1$ & $48.9 \pm 1.6$ & 89.0 \\
$\mathrm{Cd}$ & $0.15 \pm 0.01$ & $0.148 \pm 0.007$ & 101 \\
$\mathrm{~Pb}$ & $11.2 \pm 1.9$ & $11.7 \pm 1.2$ & 95.7 \\
\hline
\end{tabular}

The distribution patterns of the heavy metals in the study area are shown in Figure 2. The concentrations consisted of varied ranges, namely $0.77-5.96 \mu \mathrm{g} / \mathrm{g}$ dry weight for $\mathrm{Cu}, 11.6$ $76.1 \mu \mathrm{g} / \mathrm{g}$ dry weight for $\mathrm{Zn}, 0.03-0.19 \mu \mathrm{g} / \mathrm{g}$ dry weight for $\mathrm{Cd}$ and $2.34-22.5 \mu \mathrm{g} / \mathrm{g}$ dry weight
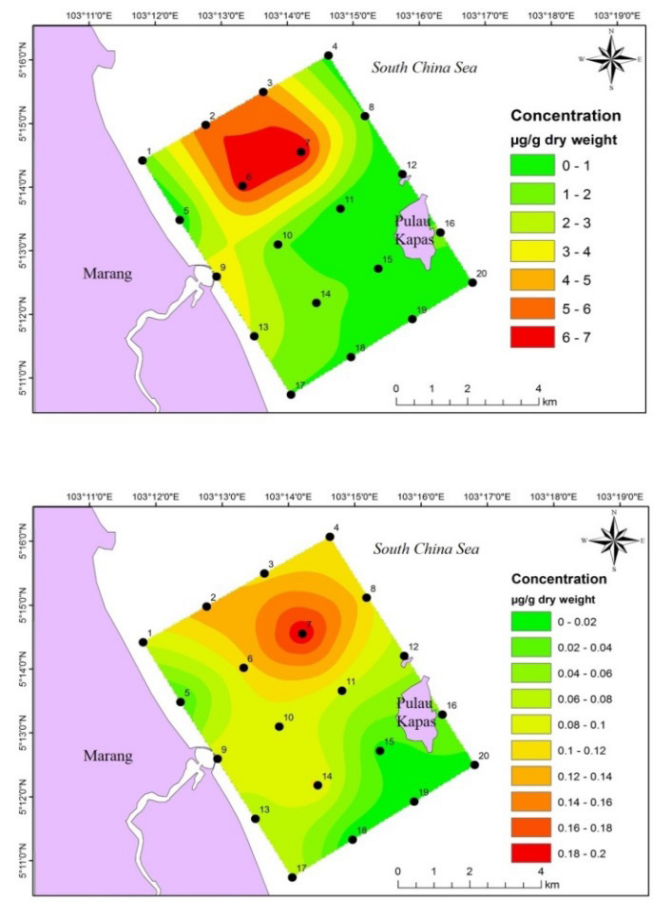

Figure 2: The distribution of $\mathrm{Cu}, \mathrm{Zn}, \mathrm{Cd}$ and $\mathrm{Pb}$ concentrations in the study area

Based on Figure 2, the distribution of heavy metals was mainly concentrated at Station 7. The concentrations of $\mathrm{Cu}, \mathrm{Zn}, \mathrm{Cd}$, and $\mathrm{Pb}$ were the highest in that particular station. Besides that, there was also a "trail" of high heavy metal concentration that could be seen clearly from the estuary of Marang River to Station 7. This indicated s that the Marang River could probably
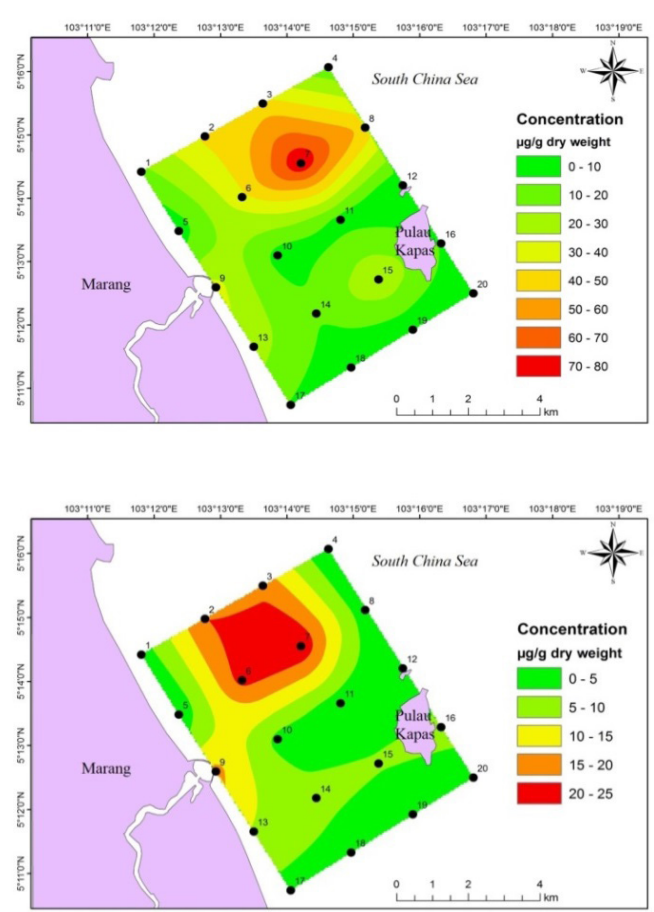

for $\mathrm{Pb}$. The average concentrations of $\mathrm{Cu}, \mathrm{Zn}$, $\mathrm{Cd}$, and $\mathrm{Pb}$ were $2.33 \pm 0.38 \mu \mathrm{g} / \mathrm{g}$ dry weight, $28.43 \pm 3.78 \mu \mathrm{g} / \mathrm{g}$ dry weight, $0.09 \pm 0.01 \mu \mathrm{g} / \mathrm{g}$ dry weight and $8.35 \pm 1.48 \mu \mathrm{g} / \mathrm{g}$ dry weight, respectively.

be the source of the heavy metal contamination that came from untreated industrial and domestic waste discharged upstream of the river (Chen et al., 2007). Kishe and Machiwa (2003) and Muniz et al. (2004), in their findings, also stated that heavy metal pollution in the marine environment mainly came from the discharge of untreated industrial and domestic waste. 
Moreover, shipping was also one of the sources of heavy metal pollution. Ship traffic in the study area could be considered heavy due to fishing and tourist activities around Pulau Kapas. The antifouling paint on boats and ships used to prevent the growth of organisms like barnacles and algae contained high amounts of $\mathrm{Cu}$ and $\mathrm{Zn}$ (Bothner et al., 1998; Orlić \& Tang, 1999). Therefore, the elevated concentration of heavy metals in the study samples could also be caused by the washout of antifouling paints from boats and ships (Guerra-García \& GarcíaGómez, 2005). The use of cheap leaded fuel in outboard engines was also a main contributor of $\mathrm{Pb}$ pollution in the study area (Nasr et al., 2006).

Although the Marang River might be the main source of heavy metal pollution, Station 9 and its surrounding areas — which were directly adjacent the estuary — did not record the highest concentration of such metals. This observation could be explained by Boström et al. (1974), which stated that heavy metals in the marine environment could be transported by prevailing currents. Therefore, the heavy metals from Marang River - and Pulau Kapas to some extent - were probably carried away by the sea current and concentrated on the sediments in Station 7 and its surrounding areas (Morillo et al., 2004).

Figure 3 shows the average percentage of clay, silt and sand in the sediment samples. Due to the uniqueness of the estuary ecosystem, fine sediments, such as silt and clay, would usually be trapped in the area and rarely washed out to sea (Duck \& Wewetzer, 2001). However, this was not observed at the Marang River.

Figure 4 shows that clay and silt were mostly found at Station 6 and Station 7, which were quite far from the estuary. This could be attributed to the sea current and tidal waves, which were influenced by the monsoon. The sea surface circulation at the study area was known to vary according to monsoon (Akhir et al., 2014).

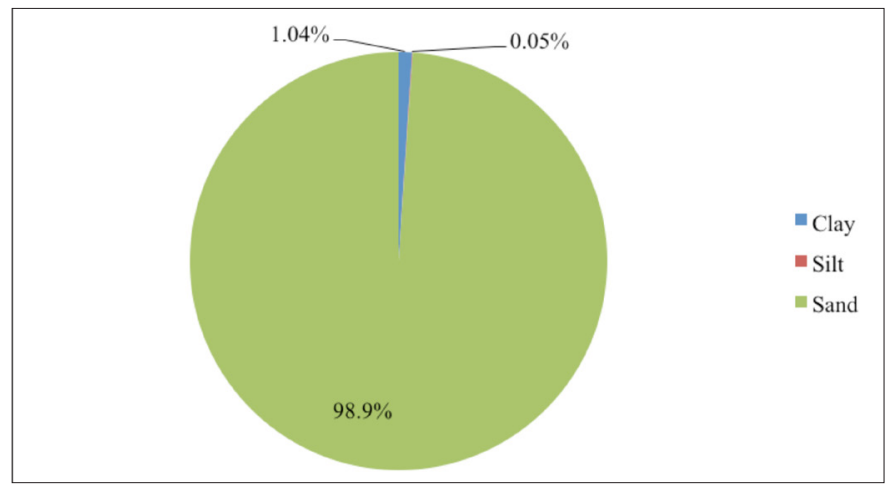

Figure 3: Average percentage of clay, silt and sand in the study area

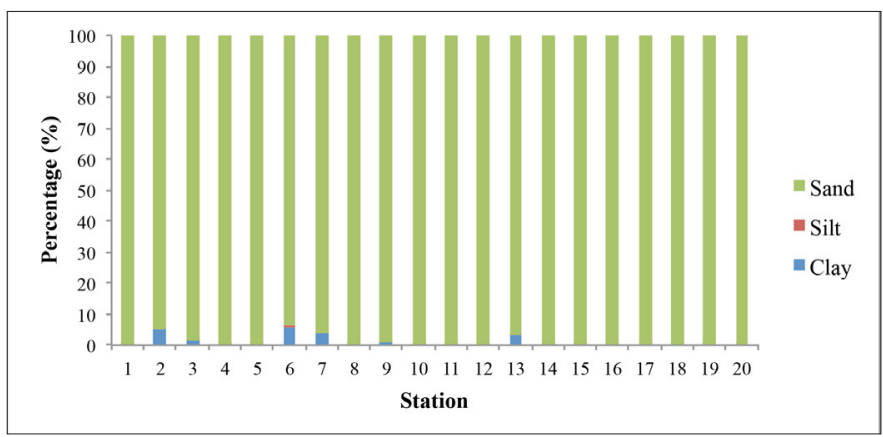

Figure 4: Percentage of sand, silt and clay from sediment samples obtained at each station 
According to Akhir and Yong (2011), the sea current would flow northward along Peninsular Malaysia during the southwest monsoon, which occurred from May to September. This was due to prevailing south westerly winds generated in the South China Sea (Raj, 1982). Since the samplings in Station 6 and 7 were conducted in October 2018, it was possible that the sediments had been carried by the northward current from the estuary to Station 6 and Station 7. Moreover, the time taken for sediments with smaller grain sizes, such as clay and silt, to sink into the ocean was very long (George et al., 2007). Hence, the fine sediments would only sink entirely into the seabed after travelling some distance.

In Figure 5, all the selected metals showed positive correlation with the mean sediment size. $\mathrm{Pb}$ had the highest correlation $(\mathrm{r}=0.857)$, followed by $\mathrm{Cu}(\mathrm{r}=0.846), \mathrm{Zn}(\mathrm{r}=0.575)$ and $\mathrm{Cd}$ $(\mathrm{r}=0.406)$. The positive correlation indicated that the concentration of heavy metals was higher in fine sediments than coarse ones. This was in line with the theory of smaller grain size adsorbing a higher concentration of heavy metals due to a larger surface area to volume ratio (Martincic et al., 1990).

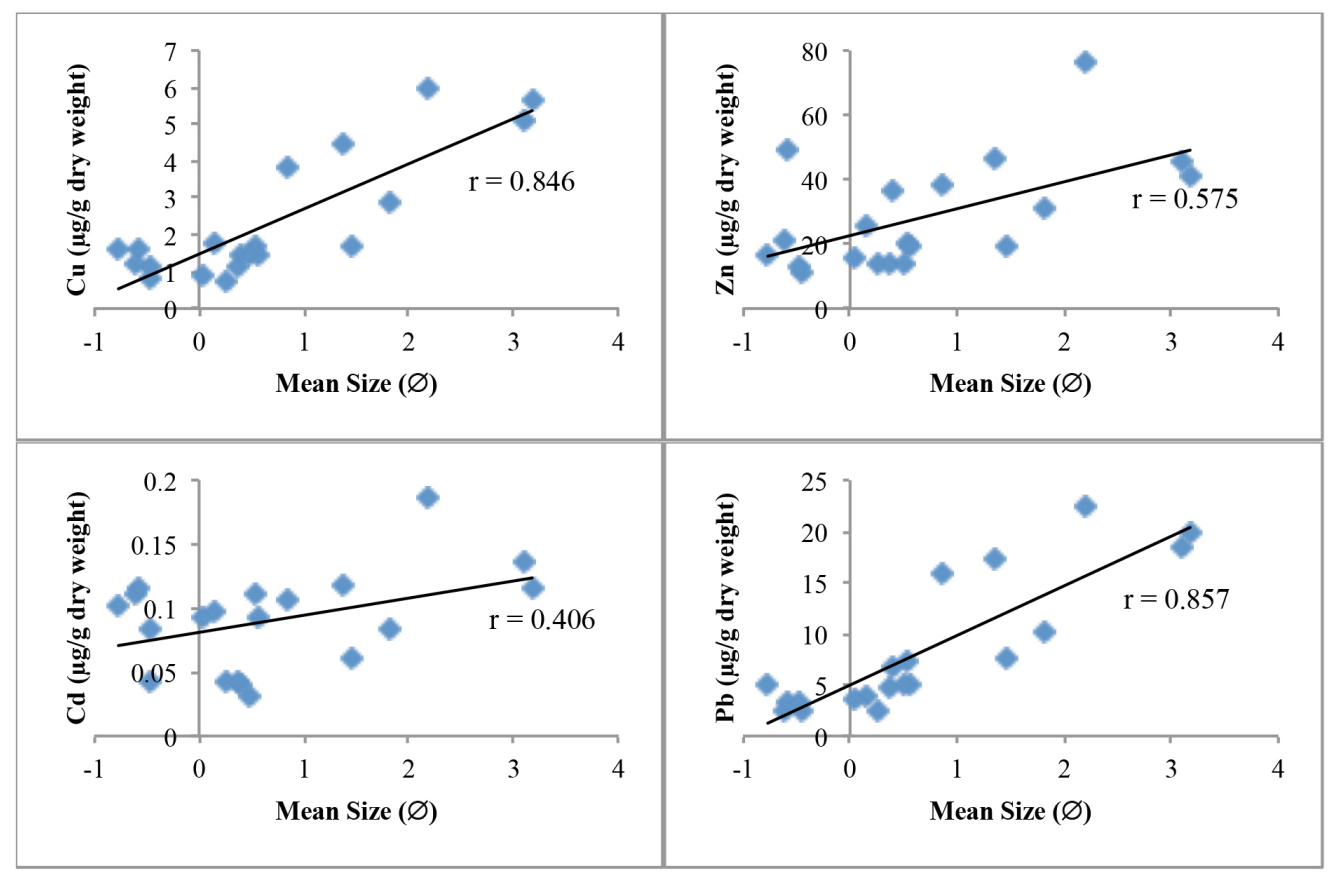

Figure 5: Correlation between selected metals $(\mathrm{Cu}, \mathrm{Zn}, \mathrm{Cd}, \mathrm{Pb})$ and sediment mean size

Table 2 shows the correlation between the heavy metals in the study area. All the metals showed a positive correlation with each other, which indicated that the natural and anthropogenic sources were similar (Amin et al., 2009). Among the metals, $\mathrm{Cu}$ had a stronger relationship with $\mathrm{Pb}$ and $\mathrm{Zn}$. This showed that $\mathrm{Cu}, \mathrm{Pb}$ and $\mathrm{Zn}$ in the study area likely came from the same sources, such as antifouling paints and leaded fuel used in ships and outboard engines. The metals might also have come from benthic organisms that had similar uptake and release mechanisms in the sediments (Broman et al., 1991).

Table 2: Correlation between heavy metals concentration

\begin{tabular}{cccc}
\hline & $\mathrm{Cu}$ & $\mathrm{Zn}$ & $\mathrm{Cd}$ \\
\hline $\mathrm{Zn}$ & 0.825 & 1 & \\
$\mathrm{Cd}$ & 0.701 & 0.749 & 1 \\
$\mathrm{~Pb}$ & 0.983 & 0.798 & 0.646 \\
\hline
\end{tabular}


$I_{\text {geo }}$ was introduced by Muller (1969) to describe heavy metal contamination in soil sediments. The formula used to calculate $I_{g e o}$ is stated in Equation 1 (Eq. 1).

$$
I_{\text {geo }}=\log _{2}\left[\frac{C_{n}}{1.5 B_{n}}\right]
$$

where $C_{n}$ is the measured concentration of metal $\mathrm{n}$ in the sediment, while $B_{n}$ is the background value for metal $\mathrm{n}$. The background values used were referred to the concentration of metals in the Upper Continental Crust reported by Wedepohl (1995). The calculated $I_{\text {geo }}$ value was used to determine the level of pollution at the sampling sites. There were seven classes of pollution as shown in Table 3 (Muller, 1969; Nowrouzi \& Pourkhabbaz, 2014).

Table 3: Pollution categories based on the Geoaccumulation Index $\left(I_{\text {geo }}\right)$

\begin{tabular}{ccc}
\hline Class & Value & Classification \\
\hline 0 & $<0$ & Unpolluted \\
1 & $0-1$ & Unpolluted to moderately polluted \\
2 & $1-2$ & Moderately polluted \\
3 & $2-3$ & Moderate to strongly polluted \\
4 & $3-4$ & Strongly polluted \\
5 & $4-5$ & Strong to extremely polluted \\
6 & $>5$ & Extremely polluted \\
\hline
\end{tabular}

The $I_{\text {geo }}$ values of the selected metals in this study are shown in the interpolation maps of the values in Figure 6. Based on Table 3, the sediment at Station 7 could be categorized as unpolluted to moderately polluted with $\mathrm{Cd}$ as the $I_{\text {geo }}$ value was 0.286 (Class 1). The sediments
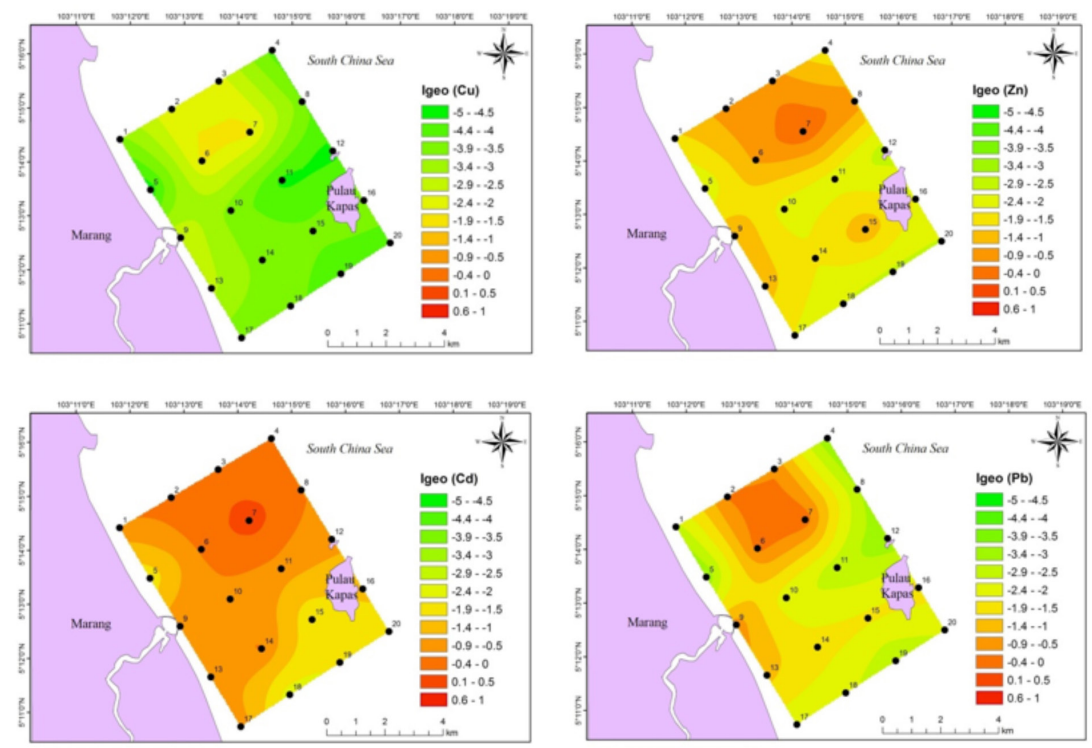

Figure 6: Interpolation maps of values of $\mathrm{Cu}, \mathrm{Zn}, \mathrm{Cd}$ and $\mathrm{Pb}$ at each station 
The PLI proposed by Tomlinson et al. (1980) in Equation 2 (Eq. 2) is used to calculate its value:

$P L I=\left(C F_{1} \times C F_{2} \times C F_{3} \times \ldots \ldots \ldots \times C F_{n}\right)^{\frac{1}{n}}$

where $\mathrm{n}$ is the number of metals. The contamination factor $(\mathrm{CF})$ is defined in Equation 3 (Eq. 3).

$$
\mathrm{CF}=\frac{\text { Metal concentration in the sediments }}{\text { Background value of the metal }}
$$

The background value of the metals was also referred to Wedepohl (1995). PLI value > 1 was considered polluted, while PLI value of $<$ 1 was considered no pollution (Tomlinson et al., 1980; Harikumar et al., 2009). Lower PLI values indicated less pollution from anthropogenic sources (Chakravarty \& Patgiri, 2009).

Figure 8 shows the PLI values at each station using their interpolation maps. Among the stations, only Station 7 was considered polluted with heavy metals because its value was more than 1 (1.13).

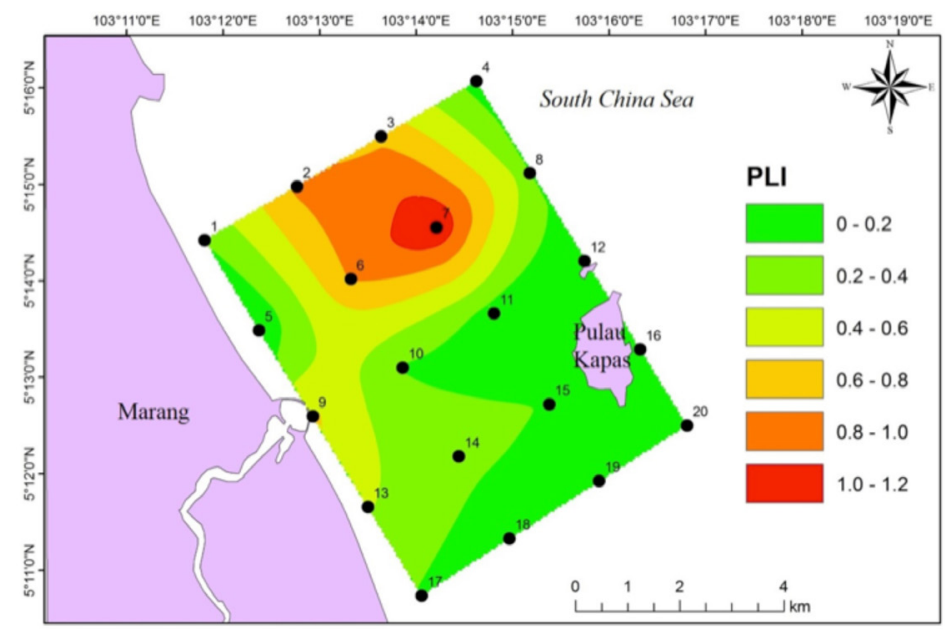

Figure 8: Interpolation map of PLI values at each station

\section{Conclusion}

Generally, marine sediments in the waters off Marang could be considered unpolluted. This was because all heavy metal concentrations were below their background values. However, only $\mathrm{Cd}$ in Station 7 was classified as Class 1, which indicated an unpolluted to moderately polluted level based on the $I_{\text {geo }}$ value obtained in this study. Furthermore, the PLI values at all stations, except Station 7, were less than 1, which indicated no pollution. Although this study found no significant pollution of heavy metals in the waters off Marang, the data could be used to enhance the safety of fishing products, where local fishermen could be cautioned against fishing in areas where high concentration of the metals were detected.

\section{Acknowledgements}

This research was funded by Universiti Malaysia Terengganu's Faculty of Science and Marine Environment and the Institute of Oceanography and Environment, which is a Higher Institution Centre of Excellence (HICoE, 66928) under the Higher Education Ministry of Malaysia. The authors wish to express their gratitude to the staff members of the Oceanography Laboratory in the Faculty of Science and Marine Environment for 
their invaluable assistance. The authors also like to thank UMT's Central Laboratory for facilitating the use of the Discovery VII vessel.

\section{References}

Abrahim, G. M. S., Parker, R. J., \& Nichol, S. L. (2007). Distribution and assessment of sediment toxicity in Tamaki Estuary, Auckland, New Zealand. Environmental Geology, 52, 1315-1323.

Akhir, M. F. M., \& Yong, J. C. (2011). Seasonal variation of water characteristics during inter-monsoon along the East Coast of Johor. Journal of Sustainability Science and Management, 6(2), 206-214.

Akhir, M. F. M., Zakaria, N. Z., \& Tangang, F. (2014). Intermonsoon variation of physical characteristics and current circulation along the east coast of Peninsular Malaysia. International Journal of Oceanography, 527587.

Amin, B., Ismail, A., Arshad, A., Yap, C. K., \& Kamarudin, M. S. (2009). Anthropogenic impacts on heavy metal concentrations in the coastal sediments of Dumai, Indonesia. Environmental Monitoring and Assessment, 148, 291-305.

Bothner, M. H., Buchholtz ten Brink, M., \& Manheim, F. T. (1998). Metal concentrations in surface sediments of Boston Harborchanges with time. Marine Environmental Research, 45(2), 127-155.

Boström, K., Joensuu, O., \& Brohm, I. (1974). Plankton: its chemical composition and its significance as a source of pelagic sediments. Chemical Geology, 14, 255-271.

Broman, D., Lindqvist, L., \& Lundbergh, I. (1991). Cadmium and zinc in Mytilus edulis L. from the Bothnian Sea and the Northern Baltic Proper. Environmental Pollution, 74, 227-244.

Chakravarty, M., \& Patgiri, A. D. (2009). Metal pollution assessment in sediments of the Dikrong River, N.E. India. Journal of Human Ecology, 27(1), 63-67.
Chen, C. W., Kao, C. M., Chen, C. F., \& Dong, C. D. (2007). Distribution and accumulation of heavy metals in the sediments of Kaohsiung Harbor, Taiwan. Chemosphere, 66, 14311440.

Dalman, O., Demirak, A., \& Balci, A. (2006). Determination of heavy metals $(\mathrm{Cd}, \mathrm{Pb})$ and trace elements $(\mathrm{Cu}, \mathrm{Zn})$ in sediments and fish of the Southeastern Aegean Sea (Turkey) by atomic absorption spectrometry. Food Chemistry, 95, 157-162.

Duck, R. W., \& Wewetzer, S. F. K. (2001). Impact of frontal systems on estuarine sediment and pollutant dynamics. The Science of the Total Environment, 266, 23-31.

Duruibe, J. O., Ogwuegbu, M. O. C., \& Egwurugwu, J. N. (2007). Heavy metal pollution and human biotoxic effects. International Journal of Physical Sciences, 2(5), 112-118.

Esen, E., Kucuksezgin, F., \& Uluturhan, E. (2010). Assessment of trace metal pollution in surface sediments of Nemrut Bay, Aegean Sea. Environmental Monitoring and Assessment, 160, 257-266.

Fu, F. L., \& Wang, Q. (2011). Removal of heavy metal ions from wastewaters: A review. Journal of Environmental Management, 92, 407-418.

Gargouri, D., Azri, C., Serbaji, M. M., Jedoui, Y., \& Montacer, M. (2011). Heavy metal concentrations in the surface marine sediments of Sfax Coast, Tunisia. Environmental Monitoring and Assessment, 175, 519-530.

George, D. A., Hill, P. S., \& Milligan, T. G. (2007). Flocculation, heavy metals $(\mathrm{Cu}$, $\mathrm{Pb}, \mathrm{Zn}$ ) and the sand-mud transition on the Adriatic continental shelf, Italy. Continental Shelf Research, 27, 475-488.

Ghrefat, H., \& Yusuf, N. (2006). Assessing Mn, $\mathrm{Fe}, \mathrm{Cu}, \mathrm{Zn}$, and $\mathrm{Cd}$ pollution in bottom sediments of Wadi Al-Arab Dam, Jordan. Chemosphere, 65, 2114-2121. 
Guerra-García, J. M., \& García-Gómez, J. C. (2005). Assessing pollution levels in sediments of a harbour with two opposing entrances. Environmental implications. Journal of Environmental Management, 77, $1-11$.

Harikumar, P. S., Nasir, U. P., \& Mujeebu Rahman, M. P. (2009). Distribution of heavy metals in the core sediments of a tropical wetland system. Environmental Science \& Technology, 6(2), 225-232.

Horowitz, A. J. (1991). A primer in sedimenttrace element chemistry. Chelsea, MI, USA: Lewis.

Islam, M.S., Ahmed, M.K., Raknuzzaman, M., Habibullah-Al-Mamun, M., Islam, M.K. (2015). Heavy metal pollution in surface water and sediment: a preliminary assessment of an urban river in a developing country. Ecological Indicators, 48, 282291.

Iwuoha, G. N., Osuji, L. C., \& Horsfall, M. Jnr. (2012). Index model analysis approach to heavy metal pollution assessment in sediments of Nworie and Otamiri Rivers in Imo State of Nigeria. Research Journal of Chemical Sciences, 2(8), 1-8.

Jian-Guo, L. Guang-Hui, L. Wan-Chen, S. JiaKuan, X. and De-Ke, W. (2010) Variations in uptake and translocation of copper, chromium and nickel among nineteen wetland plant species. Pedosphere, 20, 96103.

Kamaruzzaman, B. Y., Siti, W. A., Ong, M. C. \& Joseph, B. (2010). Spatial distribution of lead and copper in the bottom sediments of Pahang river estuary, Pahang, Malaysia. Sains Malaysiana, 39(4), 543-547.

Kamaruzzaman, B. Y., Nurulnadia, M. Y., Shazili, N. A. M., Ong, M. C., Shahbudin S, Jalal, K. C. A. \& Joseph, B. (2011) Heavy metal concentration in the surface sediment of Tanjung Lumpur mangrove forest, Kuantan, Malaysia. Sains Malaysiana, 40(2), 89-92.
Kishe, M. A., \& Machiwa, J. F. (2003). Distribution of heavy metals in sediments of Mwanza Gulf of Lake Victoria, Tanzania. Environment International, 28, 619-625.

Li, H, L., Anbang, S., Li, M. \& Zhang, X. (2013). Effect of $\mathrm{pH}$, temperature, dissolved oxygen, and flow rate of overlying water on heavy metals release from storm sewer sediments. Journal of Chemistry, 104316.

Lin, C. Y., He, M. C., Zhou, Y. X., Guo, W., \& Yang, Z. F. (2008). Distribution and contamination assessment of heavy metals in sediment of the Second Songhua River, China. Environmental Monitoring and Assessment, 137, 329-342.

Martincic, D., Kwokal, Z., \& Branica, M. (1990). Distribution of zinc, lead, cadmium and copper between different size fractions of sediments I. The Limski Canal (North Adriatic Sea). Science of the Total Environment, 95, 201-215.

Morillo, J., Usero, J., \& Gracia, I. (2004). Heavy metal distribution in marine sediments from the southwest coast of Spain. Chemosphere, $55,431-442$.

Muller, G. (1969). Index of geoaccumulation in sediments of the Rhine River. GeoJournal, 2(3), 108-118.

Muniz, P., Danulat, E., Yannicelli, B., GarcíaAlonso, J., Medina, G., \& Bícego, M. C. (2004). Assessment of contamination by heavy metals and petroleum hydrocarbons in sediments of Montevideo Harbour (Uruguay). Environment International, 29, 1019-1028.

Nasr, S. M., Okbah, M. A., \& Kasem, S. M. (2006). Environmental assessment of heavy metal pollution in bottom sediments of Aden Port, Yemen. International Journal of Oceans and Oceanography, 1(1), 99-109.

National Institute of Standards and Technology. (n.d.). SRM 1646a - Estuarine Sediment. Retrieved from http://www.speciation.net/ Database/Materials/National-Instituteof-Standards-and-Technology-NIST/ 
SRM-1646a--Estuarine-Sediment-;i789,19 February 2019.

Niu, H. Y., Deng, W. J., Wu, Q. H., \& Chen, X. G. (2009). Potential toxic risk of heavy metals from sediment of the Pearl River in South China. Journal of Environmental Sciences, 21, 1053-1058.

Nowrouzi, M., \& Pourkhabbaz, A. (2014). Application of geoaccumulation index and enrichment factor for assessing metal contamination in the sediments of Hara Biosphere Reserve, Iran. Chemical Speciation and Bioavailability, 26(2), 99105.

Nowrouzi, M., Pourkhabbaz, A. \& Rezaei M. (2014) Sequential extraction analysis of metals in sediments from the Hara Biosphere Reserve of Southern Iran. Chemical Speciation and Bioavailability, 26(4), 273-277.

Ong, M. C., Menier, D., Shazili, N. A. M., \& Kamaruzzaman, B. Y. (2013). Geochemical characteristics of heavy metals concentration in sediments of Quiberon Bay Waters, South Brittany, France. Oriental Journal of Chemistry, 29(1), 39-45.

Ong, M. C., Joseph, B., Shazili, N. A. M., Ghazali, A., \& Mohamad, M. N. (2015). Heavy metals concentration in surficial sediments of Bidong Island, South China Sea off the east coast of Peninsular Malaysia. Asian Journal of Earth Sciences, 8(3), 74-82.

Orlić, I., \& Tang, S. M. (1999). Elemental depth profiles in marine sediments of Singapore coastal waters. Nuclear Instruments and Methods in Physics Research, 150, 291297.

Pan, K., \& Wang, W-X. (2012). Trace metal contamination in estuarine and coastal environments in China. Science of the Total Environment, 421-422, 3-16.

Peng, K. Luoc, C. Loua, L. Lic, X. and Shena, Z.
(2008) Bioaccumulation of heavy metals by the aquatic plants Potamogeton pectinatus L. and Potamogeton malaianus Miq. And their potential use for contamination indicators and in wastewater treatment. Science of the Total Environment, 392, 2229.

Raj, J. K. (1982). Net directions and rates of present-day beach sediment transport by littoral drift along the East Coast of Peninsular Malaysia. Bulletin of the Geological Society of Malaysia, 15, 57-70.

Tomlinson, D. L., Wilson, J. G., Harris, C. R., \& Jeffrey, D. W. (1980). Problems in the assessment of heavy-metal levels in estuaries and the formation of a pollution index. Helgol.Wiss.Meeresunters, 33, 566575.

Wang, S. S., Cao, Z. M., Lan, D. Z., Zheng, Z. C., \& Li, G. H. (2008). Concentration distribution and assessment of several heavy metals in sediments of west-four Pearl River Estuary. Environmental Geology, 55, 963-975.

Wedepohl, K. H. (1995). The composition of the continental crust. Geochimica et Cosmochimica Acta, 59(7), 1217-1232.

Yuan, C-G., Shi, J-B., He, B., Liu, J-F., Liang, L-N., \& Jiang, G-B. (2004). Speciation of heavy metals in marine sediments from the East China Sea by ICP-MS with sequential extraction. Environment International, 30, 769-783.

Zhang, L., Ye, X., Feng, H., Jing, Y., Ouyang, T., Yu, X., Liang, R., Gao, C. \& Chen, W. (2007). Heavy metal contamination in western Xiamen Bay sediments and its vicinity, China. Marine Pollution Bulletin, 54, 974-982.

Zoumis, T., Schmidt, A., Grigorova, L., \& Calmano, W. (2001). Contaminants in sediments: remobilisation and demobilisation. The Science of the Total Environment, 266, 195-202. 
